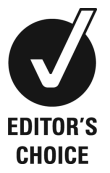

'Department of Oral and Maxillofacial Surgery, King George's Medical University, Lucknow, Uttar Pradesh, India ${ }^{2}$ King George's Medical University, Lucknow, Uttar Pradesh, India ${ }^{3}$ Department of Medicine, King George's Medical University, Lucknow, Uttar Pradesh, India ${ }^{4}$ Department of Radiodiagnosis, King George's Medical University, Lucknow, Uttar Pradesh, India

\section{Correspondence to}

Dr Hari Ram, Department of Oral and Maxillofacial Surgery, King George's Medical University, Lucknow, Uttar Pradesh 226003, India; hariram81@yahoo.com

Accepted 20 July 2014

\title{
Fracture of mandible during yawning in a patient with osteogenesis imperfecta
}

\author{
Hari Ram, ${ }^{1}$ Mohammad Shadab, ${ }^{2}$ Ajay Vardaan, ${ }^{3}$ Pallavi Aga ${ }^{4}$
}

\section{SUMMARY}

Osteogenesis imperfecta is a genetic disorder characterised by fragility and multiple fractures of bones. Clinical signs and symptoms vary depending on the type of disease. Fractures of facial bones are rare compared with load-bearing long bones. We report a case of fracture of the mandible during yawning which was managed by open reduction and internal fixation.

\section{BACKGROUND}

Osteogenesis imperfecta (OI) is a rarely seen syndrome characterised by fragility of bone. ${ }^{1}$ It is also known as brittle bone disease. OI is a genetic disorder of connective tissue resulting from mutations in the gene COL1A1 on chromosome 17 and gene COL1A2 on chromosome 7 , which encode the synthesis of two pro- $\alpha 1$ chains and pro- $\alpha 2$ chains of type I collagen. ${ }^{2-4}$ Abnormal matrix is produced by osteoblasts which does not bear an adequate mechanical load. ${ }^{5}$ Bone, dentin, sclera and ligaments have abundant type I collagen, so these structures are most commonly affected. ${ }^{6}$ The incidence of OI ranges from $1: 10000$ to $1: 20000$ births. $^{7}$

On the basis of clinical criteria, Sillence classified OI into four types, ${ }^{8}$ and further types V, VI and VII were added by Glorieux et $a l^{9}{ }^{10}$ and Ward et $a l .^{11}$ The Sillence classification remains the most commonly used.

Patients with OI have multiple bone fractures, most commonly of the extremities and especially the lower extremity which is exposed to the maximum body load. ${ }^{12}$ Facial fractures are not frequently seen but may occur during extraction of teeth. $^{13}$ Facial bones may also fracture during yawning or mastication of hard objects due to high muscular forces. Extraction of teeth in patients with $\mathrm{OI}$ is avoided because there is an increased chance of developing osteoradionecrosis. ${ }^{14}$ Bisphosphonates are used for the treatment of OI. Fracture of facial bones can be treated by either open or closed reduction, depending on the indications.

\section{CASE PRESENTATION}

CrossMark

To cite: Ram H, Shadab M, Vardaan A, et al. BMJ Case Rep Published online:

[please include Day Month Year] doi:10.1136/bcr-2013203385
A 35-year-old man presented to the Department of Oral and Maxillofacial Surgery with pain during mastication and a sudden increase in pain during a yawning episode. An extraoral examination showed slight swelling on the left side of the face. On palpation, tenderness was noted at the angle and ramus region of the mandible (figure 1).

Intraoral examination revealed poor oral hygiene. There was a history of spontaneous

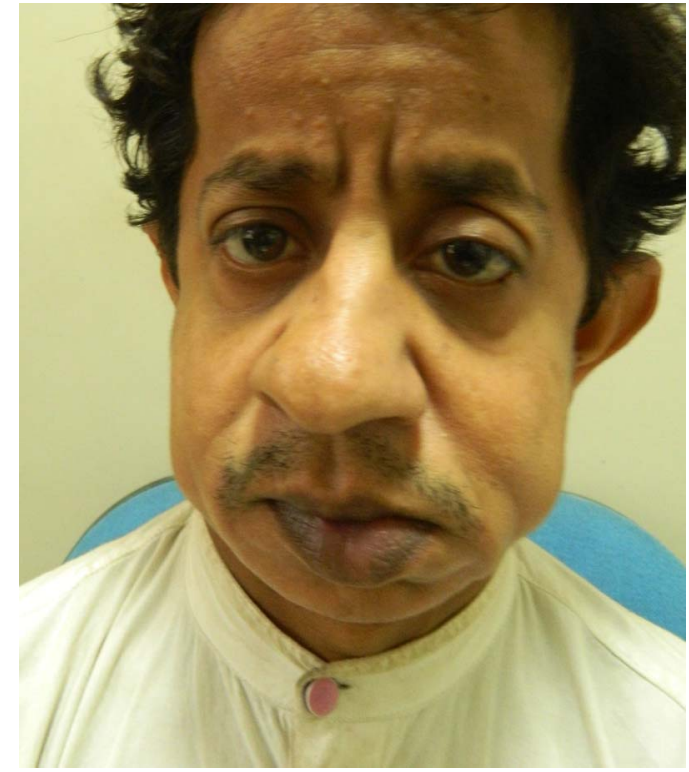

Figure 1 Photograph showing slight swelling at left side of face.

shedding of maxillary right premolars and molars. The mandibular left premolars and molars were also absent. The upper first maxillary molar was deformed and bulbous and other molar teeth were also deformed. A deep fissure was present at the midline of the palate. Occlusion was deranged and the patient was unable to close his mouth properly (figure 2).

General examination of the patient revealed a short stature of about 4 feet. There was deformity and severe bowing of the legs due to spontaneous

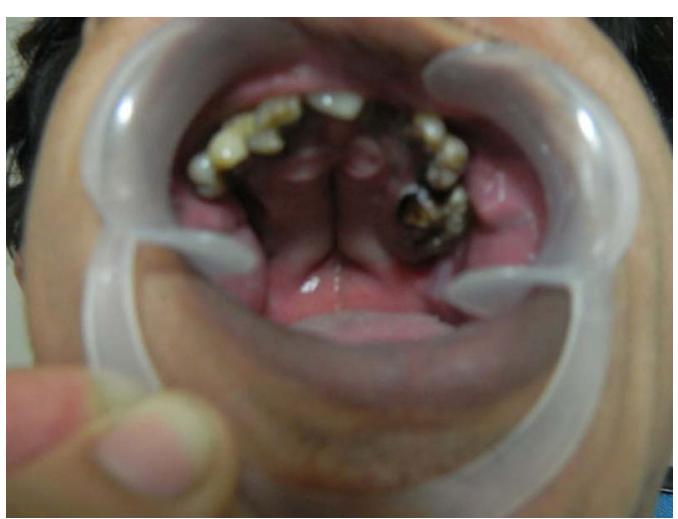

Figure 2 Intraoral view showing fissure on palate and bulky molars. 


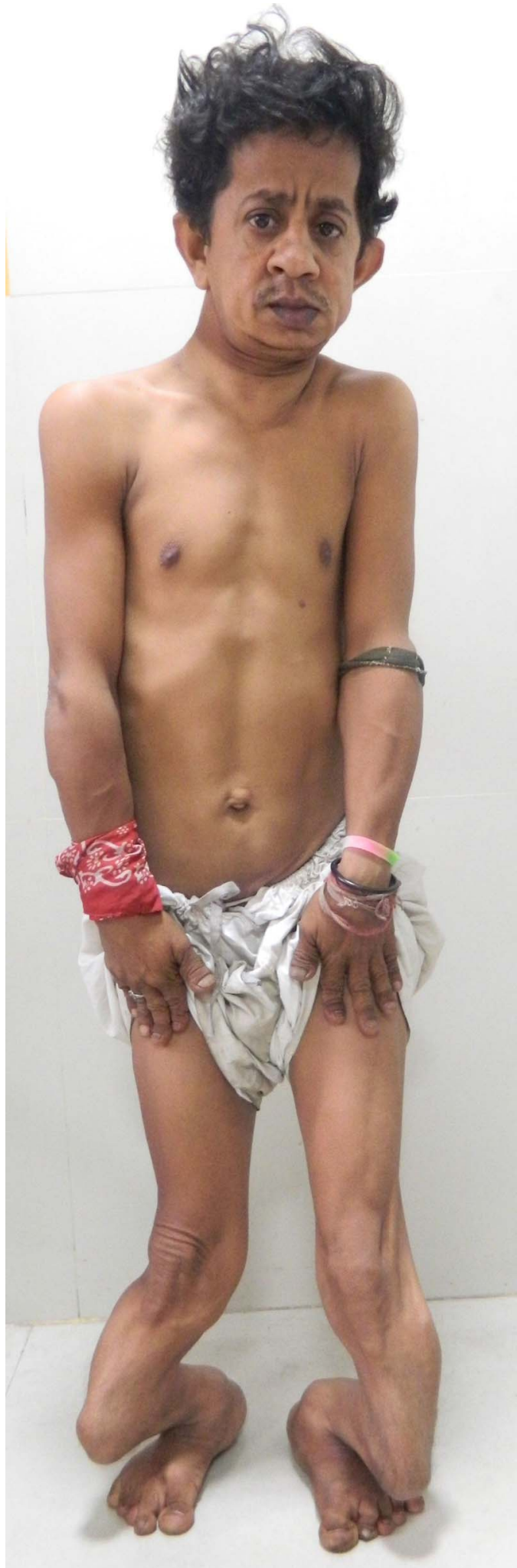

Figure 3 Photograph of patient showing deformity and bowing of legs.

fractures of both upper and lower extremities (figure 3). Osteopenia was present with multiple fractures in different healing phases in the clavicles, ribs, scapula, bilateral radius and right ulna, right and left tibia and fibula and right femur, some showing exuberant callus and pseudoarthrosis (figures 4-7).

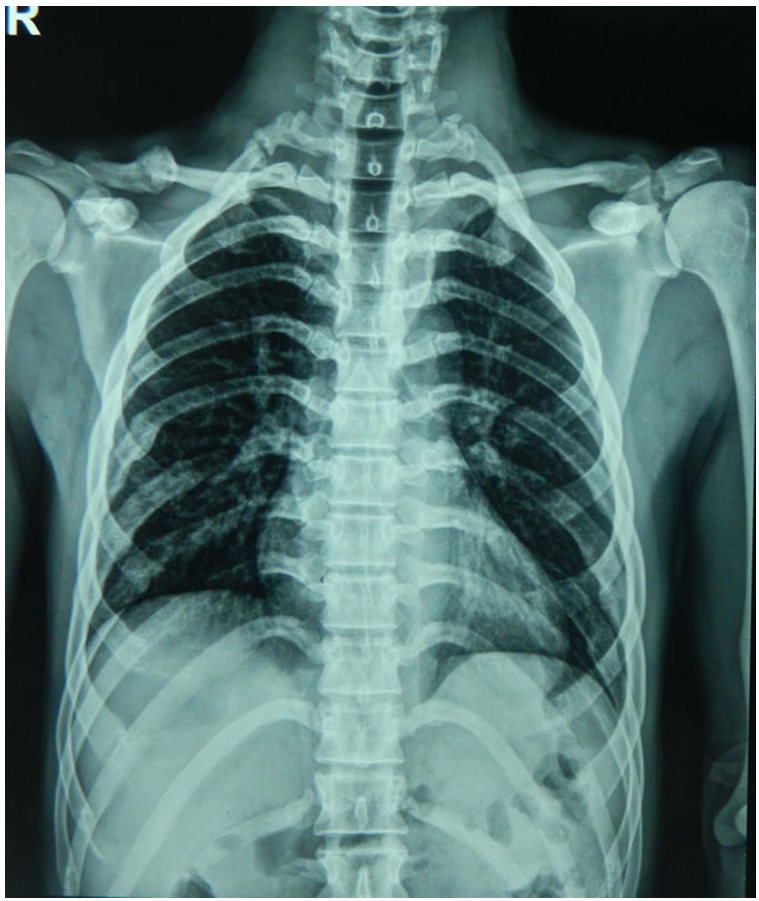

Figure 4 X-ray of chest showing fractures of clavicles, acromion and ribs.

The family history revealed that a younger brother of the patient had OI and had died 14 years previously at the age of 22 years. One brother and five sisters were normal. The personal history revealed that the patient was a chronic smoker and took 20 cigarettes per day for the last 10 years.

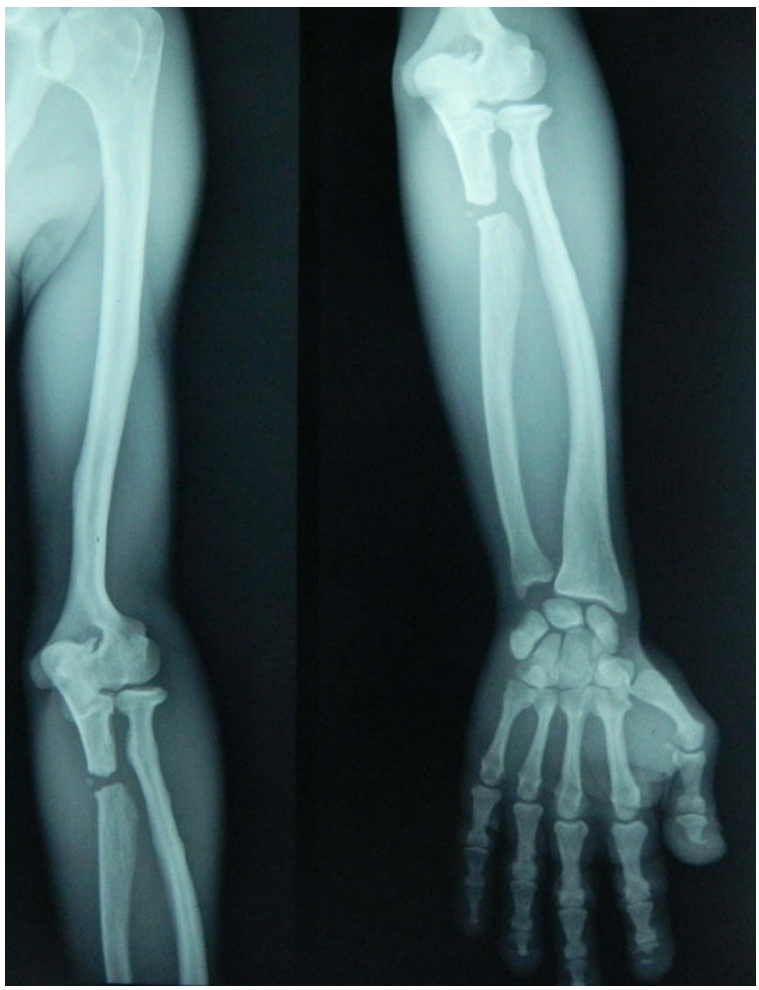

Figure $5 \quad X$-ray of left arm with forearm and hand showing fracture of left ulna with bowing of left humerus and radius. 


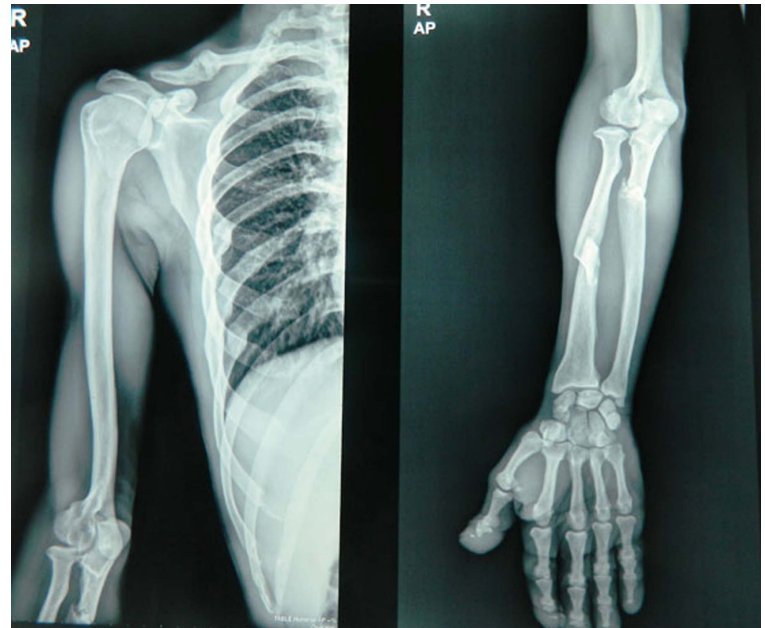

Figure 6 X-ray of right arm with forearm and hand showing bowing of humerus with fracture of ulna and radius with pseudoarthrosis formation.

\section{INVESTIGATIONS}

X-ray examination of the skull showed non-fusion of sutures which were widened and showed Wormian bones (figure 8). The colour of the sclera was light blue (figure 9). The face was larger than normal and the fingers were short and club-shaped but maintained the nail plate and bed angle suggestive of pseudoclubbing (figure 10). The patient had a low bone mineral density. Audiometric examination revealed normal hearing. On the basis of the above findings, a clinical diagnosis of OI type IV was made.

An orthopantomogram (OPG) showed thin bone and deformed teeth; both condyles were unusually elongated. The mandible was thinned out with a fracture at the left ramus of the mandible causing upward displacement of the ramus (figure 11). All haematological and biochemical investigations were within normal limits. The ECG was also normal.

\section{DIFFERENTIAL DIAGNOSIS}

Hajdu-Cheney syndrome

Serpentine fibula syndrome

Skeletal dysplasia

Rickets

Idiopathic osteoporosis

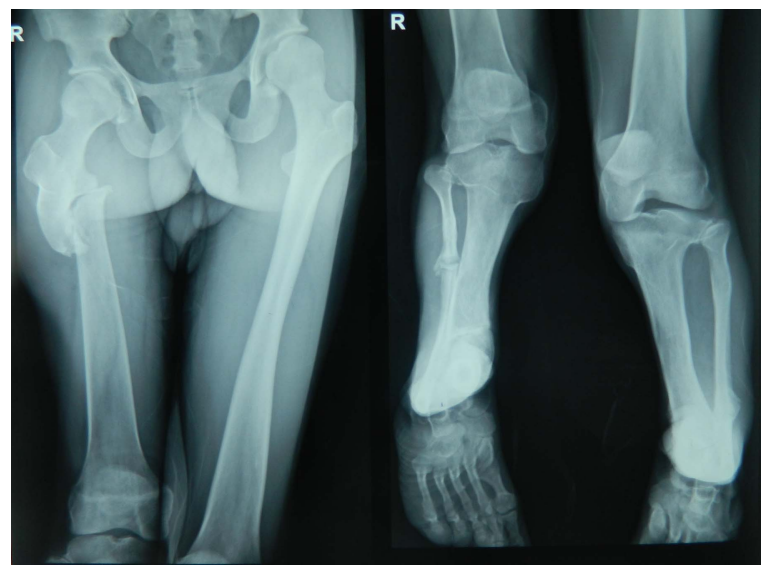

Figure 7 X-ray showing fracture of femur with pseudoarthrosis and of fibula with shortening of bones of leg.

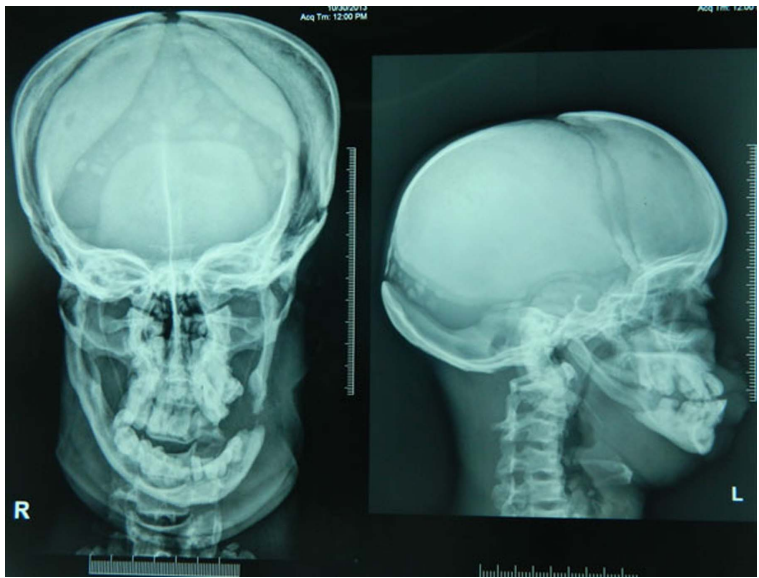

Figure 8 X-ray of skull showing non-fusion of cranial sutures, Wormian bones and fracture of mandible.

\section{TREATMENT}

Surgery was performed under general anaesthesia. An incision was made in the submandibular region and the fracture site was exposed and reduced. The ideal treatment is placement of two miniplates but, because the bones were thin and fragile, only one plate could be placed leading to incomplete reduction of the fracture. However, this shortcoming was overcome by

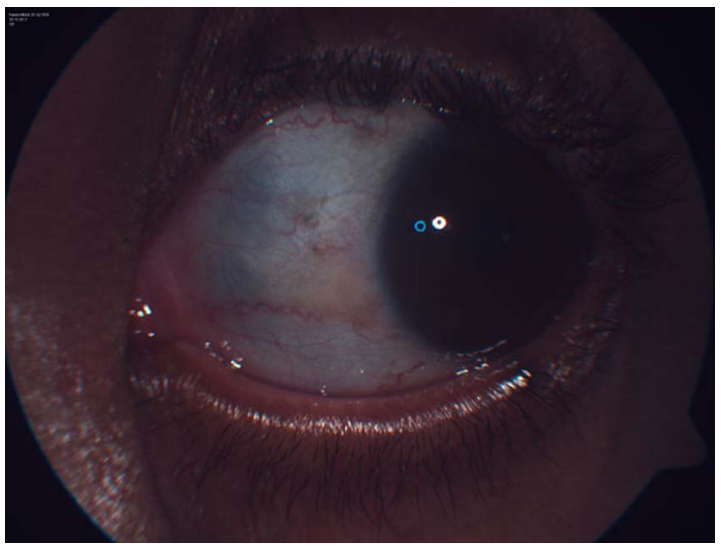

Figure 9 Photograph showing light blue sclera of eye.

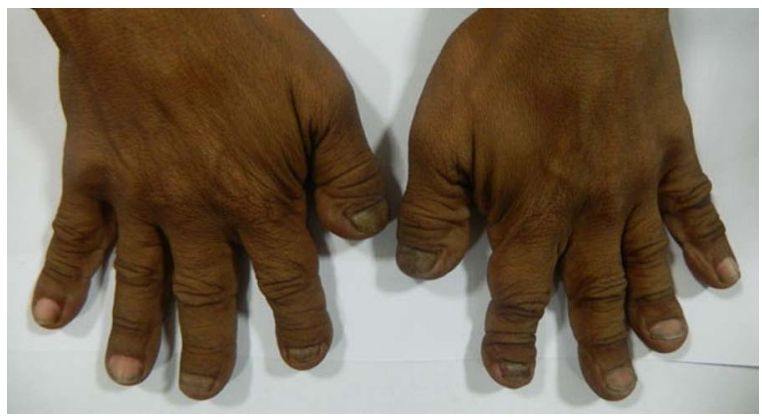

Figure 10 Photograph showing pseudoclubbing of fingers. 


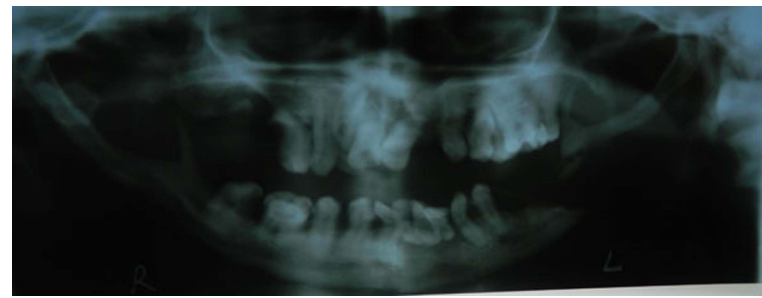

Figure 11 Orthopantomogram showing fracture of mandible.

intermaxillary fixation for 45 days (figures 12 and 13). A soft diet was advised for 1 month.

\section{OUTCOME AND FOLLOW-UP}

The postoperative course was uneventful and the patient recovered well (figure 14). He was followed up regularly and no complication was seen 6 months after surgery.

\section{DISCUSSION}

Multiple fractures of extremities are common in patients with OI. Deformity and bowing of the long bones are most frequently seen

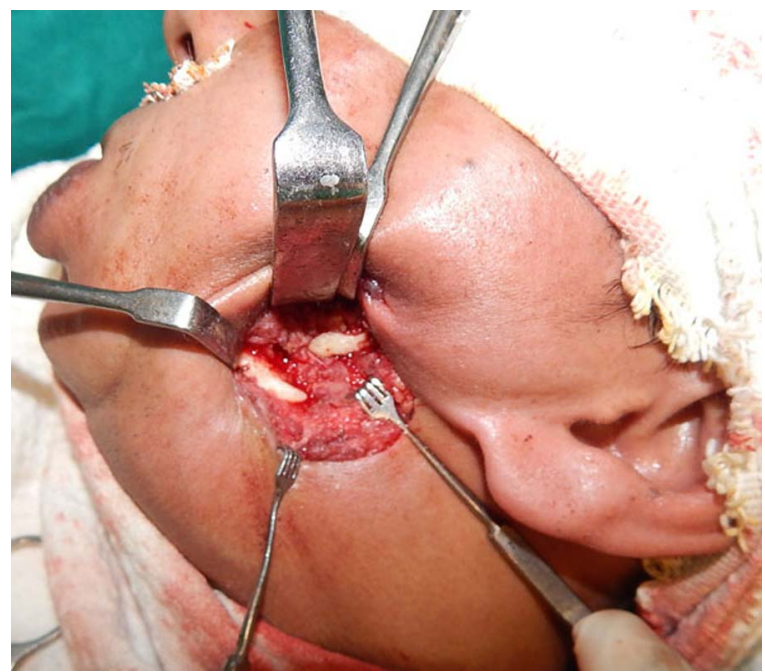

Figure 12 Intraoperative photograph showing exposed fracture site.

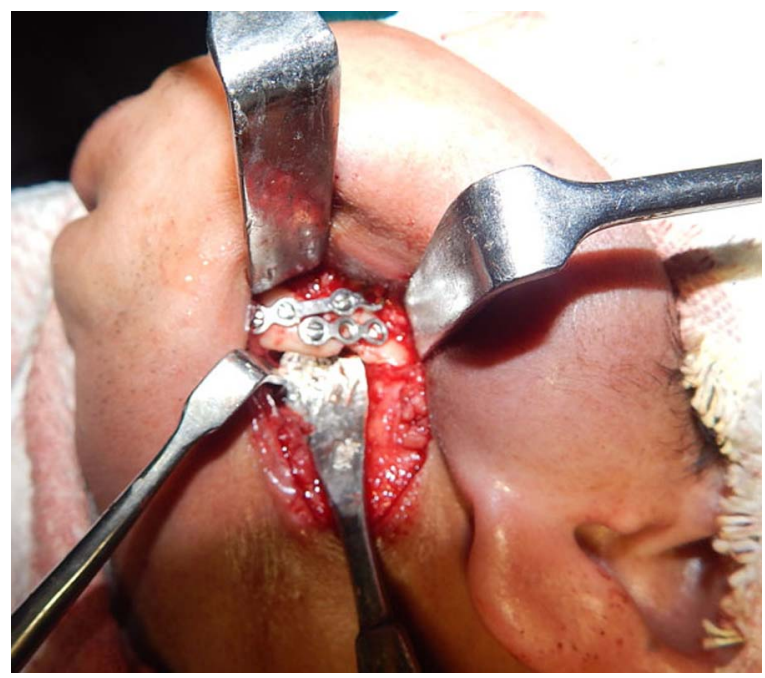

Figure 13 Intraoperative photograph showing reduced fracture and miniplates.

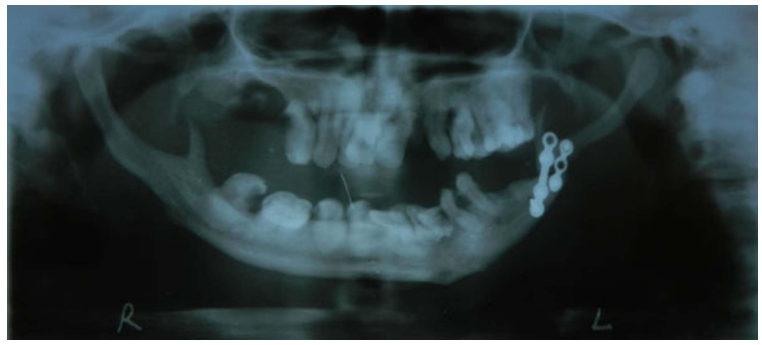

Figure 14 Postoperative orthopantomogram.

in these patients. Deafness, short stature, blue sclera, joint laxity, kyphosis, scoliosis, pigeon-shaped chest and Wormian bones of the skull may also be seen. ${ }^{15}{ }^{16}$ Associated dental symptoms may occur with dentinogenesis imperfecta, grey-brown or yellow brittle teeth and bulky crown and malocclusion. ${ }^{12}$ This patient was of short stature with severe bowing of the legs and he was unable to walk without the help of an attendant or a stick. Bulky first molars and a deep fissure at the mid-palate were also noted. Wormian bones of the skull with non-fusion of cranial sutures were seen. The deep fissure would have been caused by non-fusion of the mid-palatal suture.

Some cases of fractured jaw bones during tooth extraction have been reported in the literature. ${ }^{12}$ To the best of our knowledge, no case of spontaneous fracture has been reported in the English literature during yawning and our patient is probably the first reported case of spontaneous fracture in a patient with OI. The patient had poor oral hygiene which would have caused vertical bone loss and produced further weakness of the bone.

No treatment is available for OI as it is a genetic disease. However, bisphosphonates including pamidronate, zoledronate, alendronate and risedronate have been used by clinicians. Bisphosphonates interfere with osteoclastic activity by preventing, inhibiting and early apoptosis of osteoclasts. They increase the bone density so the frequency of fractures is decreased and ultimately the quality of life is improved. ${ }^{17} 18$ High doses of bisphosphonates may cause osteoradionecrosis.

The limiting factor in OI is the fragility of the bones which are frequently fractured. Although fractures of facial bones are rarely seen, they need special attention. Fracture of dentate fragments and non-displaced fractures can be treated by closed reduction but displaced fractures and fractures beyond the angle of the mandible pose difficulty in treatment and need open reduction and fixation. Surgery in these patients must be undertaken with particular care as they are compromised, having a short neck, kyphosis, scoliosis, pectus carinatum (pigeon chest) or pectus excavatum, ${ }^{15}$ cardiac abnormalities, bleeding due to platelet dysfunction and hyperthermia. ${ }^{19} 20$

\section{Learning points}

- Osteogenesis imperfecta (OI) is a rare disease characterised by bone fragility and multiple fractures.

- Fractures of facial bones are rarely seen in Ol but may occur during tooth extraction or minor trauma.

- Dental extraction should be avoided in these patients; if essential, it should be done very carefully.

- Fracture of the mandible may occur during yawning if there is bone loss due to poor periodontal health.

- Pseudoclubbing may also be seen in patients with 0 . 
Contributors HR prepared the manuscript. MS searched the web for articles. AV helped in manuscript preparation. PA performed radiological investigations.

Competing interests None.

Patient consent Obtained.

Provenance and peer review Not commissioned; externally peer reviewed.

\section{REFERENCES}

1 Elmrini A, Boujraf S, Marzouki A, et al. Osteogenesis imperfecta tarda. A case report. Nig J Orthop Trauma 2006;5:61-2.

2 Byers P. Osteogenesis imperfecta. In: Royce PM, Steinmann B, eds. Connective tissue and its heritable disorders. New York: Wiley-Liss, 1993:317-50.

3 Byers PH, Wallis GA, Willing MC. Osteogenesis imperfecta: translation of mutation to phenotype. J Med Genet 1991;28:433-42.

4 De Paepe A, Nuytinck L, Raes M, et al. Homozygosity by descent for a COL1A2 mutation in two sibs with severe osteogenesis imperfecta and mild clinical expression in the heterozygotes. Hum Genet 1997;99:478-83.

5 Huber MA. Osteogenesis imperfecta. Oral Surg Oral Med Oral Pathol Oral Radiol Endod 2007;103:314-20.

6 Tsai CL, Lin YT, Lin YT. Dentinogenesis imperfecta associated with osteogenesis imperfecta: report of two cases. Chang Gung Med J 2003;26:138-43.

7 Talabani JA, Shubbar Al, Mustafa KE. Major congenital malformations in United Arab Emirates (UAE): need for genetic counselling. Ann Hum Genet 1998;62:411-18.

8 Sillence DO, Senn A, Danks DM. Genetic hetrogeneity in osteogenesis imperfecta. J Med Genet 1979;16:101-16.

9 Glorieux FH, Rauch F, Plotkin $\mathrm{H}$, et al. Type $\mathrm{V}$ osteogenesis imperfecta: a new form of brittle bone disease. J Bone Miner Res 2000;15:1650-8.
10 Glorieux FH, Ward LM, Rauch F, et al. Osteogenesis imperfecta type VI: a form of brittle disease with a mineralization defect. J Bone Miner Res 2002;

17:30-8.

11 Ward LM, Rauch F, Travers R, et al. Osteogenesis imperfecta type VII: an autosomal recessive form of brittle bone disease. Bone 2002:31:12-18.

12 Gallego L, Junquera L, Pelaz A, et al. Pathological mandibular fracture after simple molar extraction in a patient with osteogenesis imperfecta treated with alendronate. Med Oral Patol Oral Cir Bucal 2010;15:895-7.

13 Feifel $\mathrm{H}$. The surgical treatment of mandibular fractures in a child with osteogenesis imperfecta. Int J Oral Maxillofac Surg 1996;25:360-2.

14 Schwartz S, Joseph C, lera D, et al. Bisphosphonates, osteonecrosis, osteogenesis imperfecta and dental extractions: a case series. J Can Dent Assoc 2008;74:537-42.

15 Partridge BL. Skin and bone disorders. In: Katz J, Benumof JL, Kadis LB, eds. Anesthesia and uncommon diseases. 3rd edn. Philadelphia: WB Saunders, 1990:577-8.

16 Moog U, Maroteaux P, Schrander-Stumpel CT, et al. Two sibs with an unusual pattern of skeletal malformations resembling osteogenesis imperfecta: a new type of skeletal dysplasia? J Med Genet 1999:36:856-8.

17 Siddiqi A, Payne AG, Zafar S. Bisphosphonate-induced osteonecrosis of the jaw: a medical enigma? Oral Surg Oral Med Oral Pathol Oral Radiol Endod 2009;108:1-8.

18 Hickey J, Lemons D, Waber $\mathrm{P}$, et al. Bisphosphonate use in children with bone disease. J Am Acad Orthop Surg 2006;14:638-44.

19 Stein D, Kloster FE. Valvular heart disease in osteogenesis imperfecta. Am Heart $J$ 1977;94:637-41.

20 Hathaway WE, Solomons CC, Ott J. Abnormalities of platelet function in osteogenesis imperfecta. Clin Res 1970;18:209.

Copyright 2014 BMJ Publishing Group. All rights reserved. For permission to reuse any of this content visit http://group.bmj.com/group/rights-licensing/permissions.

BMJ Case Report Fellows may re-use this article for personal use and teaching without any further permission.

Become a Fellow of BMJ Case Reports today and you can:

- Submit as many cases as you like

- Enjoy fast sympathetic peer review and rapid publication of accepted articles

- Access all the published articles

- Re-use any of the published material for personal use and teaching without further permission

For information on Institutional Fellowships contact consortiasales@bmjgroup.com

Visit casereports.bmj.com for more articles like this and to become a Fellow 